\title{
VOLCANIC ACTIVITY IN ALASKA: SUMMARY OF EVENTS AND RESPONSE OF THE ALASKA VOLCANO OBSERVATORY 1993
}

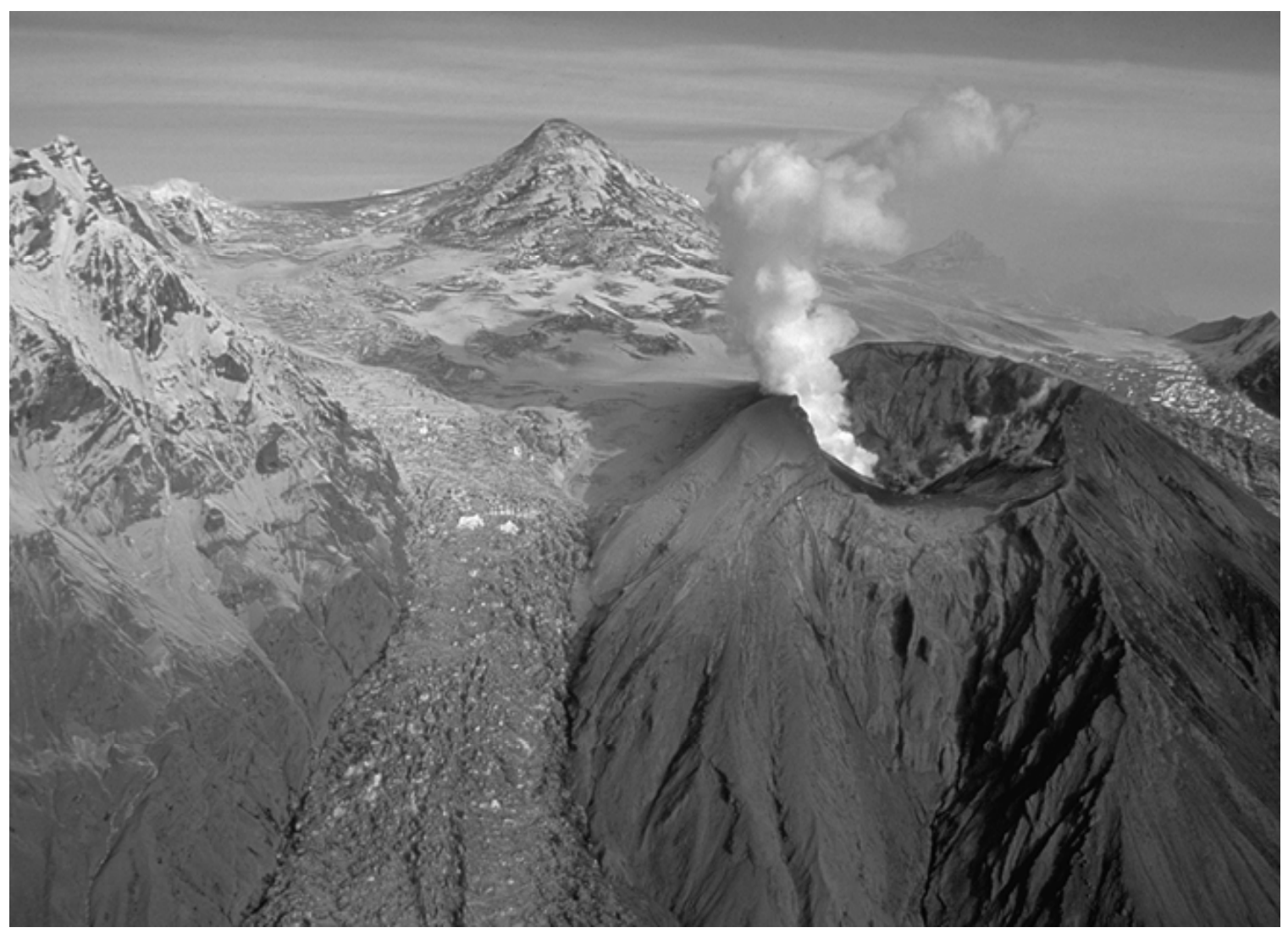

U.S. GEOLOGICAL SURVEY OPEN-FILE REPORT 96-24

\section{U.S. DEPARTMENT OF THE INTERIOR}

\section{By}

Christina A. Neal, Robert G. McGimsey, and Michael P. Doukas

This report is preliminary and has not been reviewed for conformity with U.S. Geological Survey editorial standards or with the North American Stratigraphic Code. Any use of trade, product, or firm names is for descriptive purposes only and does not imply endorsement by the U.S. Government.1996 
COVER PHOTO: South flank of Mount Spurr volcano. A steam column emanates from the Crater Peak vent, site of the 1992 eruptions. Photograph by C. A. Gardner, USGS, 926-92. 


\section{INTRODUCTION}

During 1993, the Alaska Volcano Observatory (AVO) responded to episodes of eruptive activity or false alarms at nine volcanic centers in the state of Alaska. Additionally, as part of a formal role in KVERT (the Kamchatkan Volcano Eruption Response Team), AVO staff also responded to eruptions on the Kamchatka Peninsula, details of which are summarized in Miller and Kirianov (1993).

In 1993, AVO maintained seismic instrumentation networks on four volcanoes of the Cook Inlet region--Spurr, Redoubt, Iliamna, and Augustine--and two stations at Dutton Volcano near King Cove on the Alaska Peninsula. Other routine elements of AVO's volcano monitoring program in Alaska include periodic airborne measurement of volcanic SO2 and CO2 at Cook Inlet volcanoes (Doukas, 1995) and maintenance of a lightning detection system in Cook Inlet (Paskievitch and others, 1995).

Since many of Alaska's volcanoes are on the remote and sparsely populated Alaska Peninsula and Aleutian Islands, AVO receives notification of distant eruptive activity from a variety of sources: pilot reports, ground or ship-based observations, and analysis of satellite imagery. AVO's response to reported volcanic activity varies depending on the source and content of the observation. After receiving a report and possibly conducting follow-up investigation of the factual information, AVO usually contacts the National Weather Service (NWS) and Federal Aviation Administration (FAA) for corroboration and/or formal notification. For a true eruption, an established call-down procedure and formal notification process involving other government agencies, air carriers, facilities at risk, and the media are initiated. If no confirming information is forthcoming, a notation is made in AVO logs and no further action is taken. A special information release may be distributed if eruptive activity is confirmed; the event(s) are summarized in the AVO weekly update issued each Friday. Further information concerning a remote volcanic event is released on an as-needed basis until it is determined that the activity has waned significantly or ceased.

This report presents a summary of responses to reported volcanic activity in Alaska during 1993. Only those events which resulted in a significant investment of AVO staff time and energy (here defined arbitrarily as at least several hours for reaction, tracking, and followup) are included. Typically, over the course of any given year, AVO receives many dozens of phone calls reporting steaming, unusual cloud sightings, or eruption rumors. Most of these are dealt with rapidly (less than 1 hour) and are not tabulated in this report. The phrase "false alarm", used to characterize several responses, is an eruption report or a report of unusual activity that is subsequently determined to be normal or enhanced fumarolic activity, weather-related phenomena, or a non-volcanic event. 
Brief descriptions of volcanic activity and the accompanying AVO response are presented in geographical order from northeast to southwest along the Wrangell-Aleutian volcanic arc (fig. 1). All elevations are reported as above sea level (ASL) unless otherwise noted. Times are reported as Alaska Standard (AST) or Alaska Daylight (ADT). A summary of volcanic activity is presented in Table 1 . False alarms that required a significant response are summarized in Table 2.

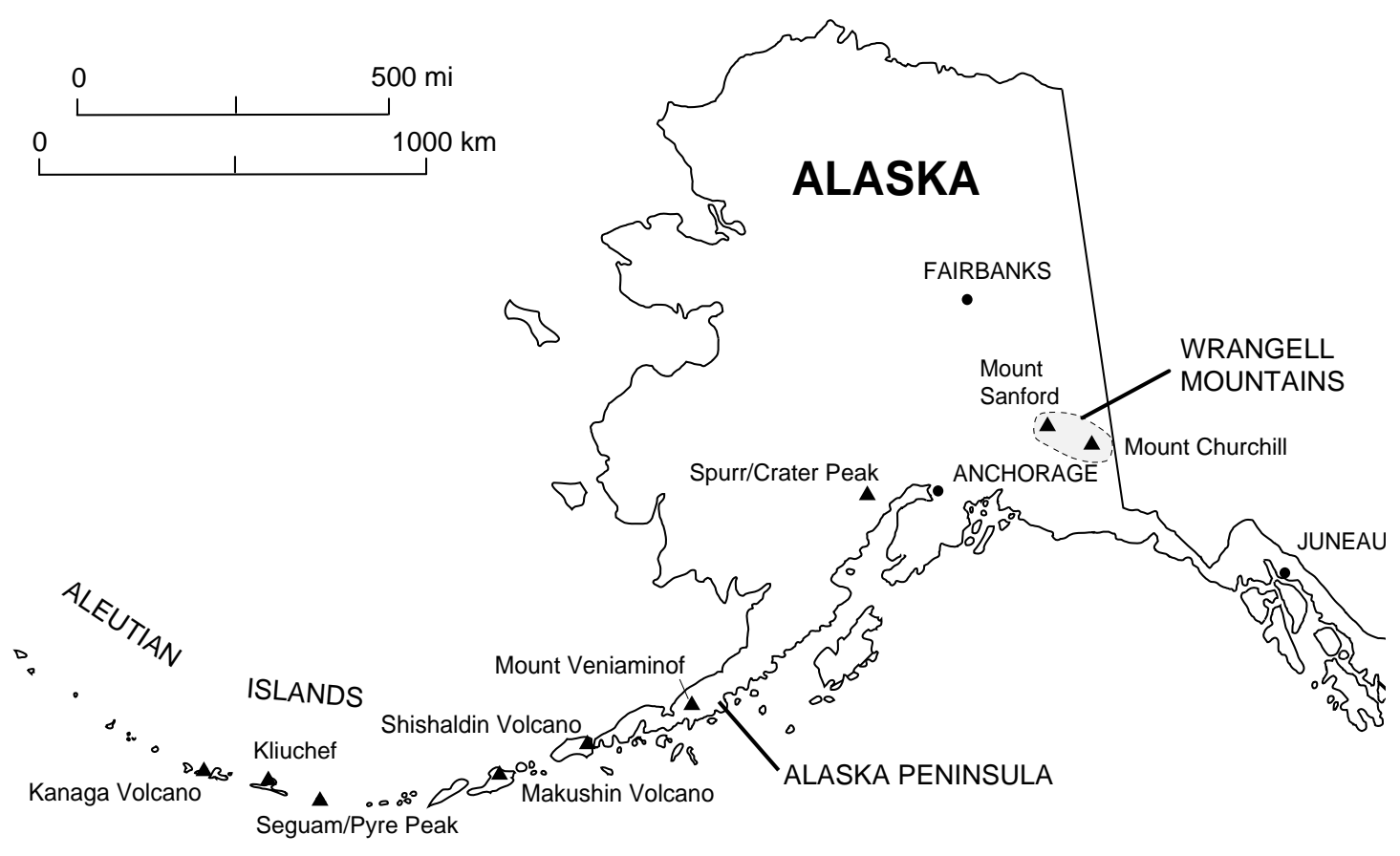

Figure 1. Locations of volcanoes (triangles) mentioned in this report.

\section{MOUNT CHURCHILL}

$61^{\mathrm{o}} 25^{\prime} \mathrm{N} 141^{\mathrm{o}} 42^{\prime} \mathrm{W} 4,766 \mathrm{~m}(15,638 \mathrm{ft})$

(FALSE ALARM)

Flurry of earthquakes near Churchill; tectonic aftershocks.

On April 5-6, 1993, seven earthquakes were located in the general vicinity of Mount Churchill, a late Holocene volcano in the eastern Wrangell Mountains and the source of the White River Ash (Richter and others, 1995a). Analysis of the seismicity by AVO seis- 
mologists indicated a tectonic rather than volcanic source. The tectonic nature of the earthquake swarm was mentioned in the weekly update of April 9, 1993.

\section{MOUNT SANFORD}

$62^{\circ} 13^{\prime} \mathrm{N} 144^{\mathrm{o}} 7^{\prime} \mathrm{W} \quad 4,949 \mathrm{~m}(16,237 \mathrm{ft})$

(FALSE ALARM)

Ground observers report unusual cloud formations over Mount Sanford in early April, 1993; possible result of avalanche activity off steep south face.

Mount Sanford is a dissected shield volcano and the highest volcano in the Wrangell volcanic field (fig. 2). Its south face has a vertical relief of more than $2440 \mathrm{~m}$ (8000 ft). This wall is the source of nearly continuous rock, snow, and ice-falls, some energetic enough to produce anomalous vapor plumes (Carl Benson, personal communication). There is no record of historical eruptive activity at Mount Sanford. The youngest lava flows are estimated to be $100 \mathrm{ka}$ old (Richter, 1991; Richter and others, 1995b.)

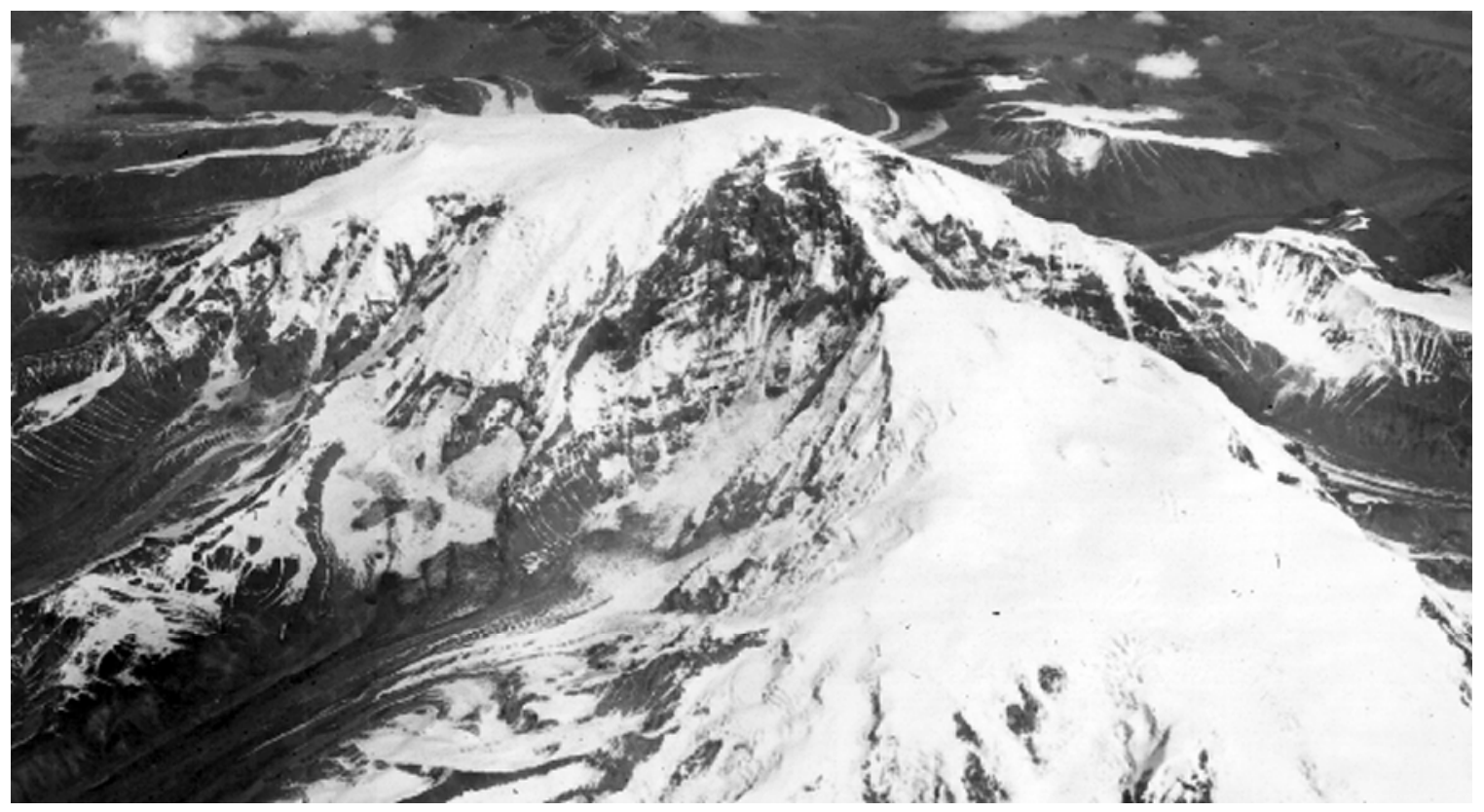

Figure 2. Oblique aerial view south face of Mount Sanford. U.S. Army-Air Force trimetrogon photo, June 15, 1948.

Ground observers in Glennallen reported unusual white cloud formations over Mount Sanford on April 5 and 6, 1993. Another report on April 8, 1993, indicated that the mountain was "steaming" from low on the east or south side (there were conflicting reports) and the resultant cloud was boiling up the flank to an estimated 5,000 $\mathrm{ft}(1,524 \mathrm{~m})$ over the top of 
the peak. This level of apparent activity was more than this observer had noted in 21 years of viewing the volcano. Given the history of rock and ice falls from the shear south flank of the mountain and the fact that the phenomenon was short-lived, AVO concluded that the observations were probably related to a large avalanche(s) or to unusual orographically induced weather clouds. No mention of the event was made in the AVO weekly update.

\section{MOUNT SPURR \\ $61^{\mathrm{o}} 18^{\prime} \mathrm{N} 152^{\circ} 15^{\prime} \mathrm{W} \quad 3,374 \mathrm{~m}(11,069 \mathrm{ft})$ \\ CRATER PEAK $61^{\circ} 16^{\prime} \mathrm{N} 152^{\circ} 14^{\prime} \mathrm{W} \quad 2,309 \mathrm{~m}(7,575 \mathrm{ft})$ \\ (FALSE ALARMS; DECLINING SEISMICITY FROM 1992 ERUPTIONS) \\ Seismic activity in response to regional earthquake on 3-14-93. Glacial outburst on 6-29-93 produces strong, tremor-like seismicity on Spurr network. Volcanic seismic- ity declines to near background levels from 1992 eruptions.}

Mount Spurr is one of the most active volcanoes of Cook Inlet. The Crater Peak vent on the south flank of the volcano was the site of three subplinian eruptions in 1992 (see cover page; Eichelberger and others, 1995 and references therein).

In 1993, seismicity at Mount Spurr continued to decline from 1992 eruptive levels and on March 5, AVO downgraded the level of concern color code to GREEN (Eichelberger and others, 1995). On March 13, a swarm of tremor and small magnitude volcano-tectonic earthquakes occurred directly beneath Crater Peak following a regional earthquake. The increase in activity lasted approximately one hour. On June 29, AVO staff noted the sudden appearance of tremor-like seismicity on several Spurr stations; fortuitously, an AVO field crew was in the area and able to verify that the source of the signal was an outburst of meltwater from the Kidazgeni Glacier (Nye and others, 1995). An explanation of the activity was released in two special updates on June 29, 1993.

\section{MOUNT VENIAMINOF}

$56^{\circ} 10^{\prime} \mathrm{N} 159^{\circ} 23^{\prime} \mathrm{W} 2,156 \mathrm{~m}(7,073 \mathrm{ft})$ active cone

$2,507 \mathrm{~m}(8,225 \mathrm{ft})$ caldera rim

Low-level strombolian eruptive activity and sporadic lava flows from an intracaldera cinder cone 7-30-93 into 1994. Ash and steam plumes usually < $1 \mathrm{~km}$ above summit; fallout of fine ash reported in Port Heiden on one occasion. 
Mount Veniaminof, located $760 \mathrm{~km}$ (500 mi) southwest of Anchorage on the Alaska Peninsula, is a broad conical stratovolcano with an ice-filled summit caldera about $10 \mathrm{~km}$ in diameter. Two cinder cones protrude through the ice-cap, one of which has been the center of historical eruptive activity. The eruptive activity that began in 1993 is similar in style to the 1983-84 eruption of Mount Veniaminof (Yount and others, 1985). The nearest settlements to the volcano are Perryville, $34 \mathrm{~km}$ (21 mi) SE, and Chignik Lake, Chignik Lagoon and Chignik, $40 \mathrm{~km}(25 \mathrm{mi}), 55 \mathrm{~km}$ (34 mi), and $60 \mathrm{~km}$ (37 mi) mi ENE of the volcano, respectively (fig. 3). The village of Meshik/Port Heiden is on the Bering Sea coast $96 \mathrm{~km}$ (60 mi) NE of Mount Veniaminof.

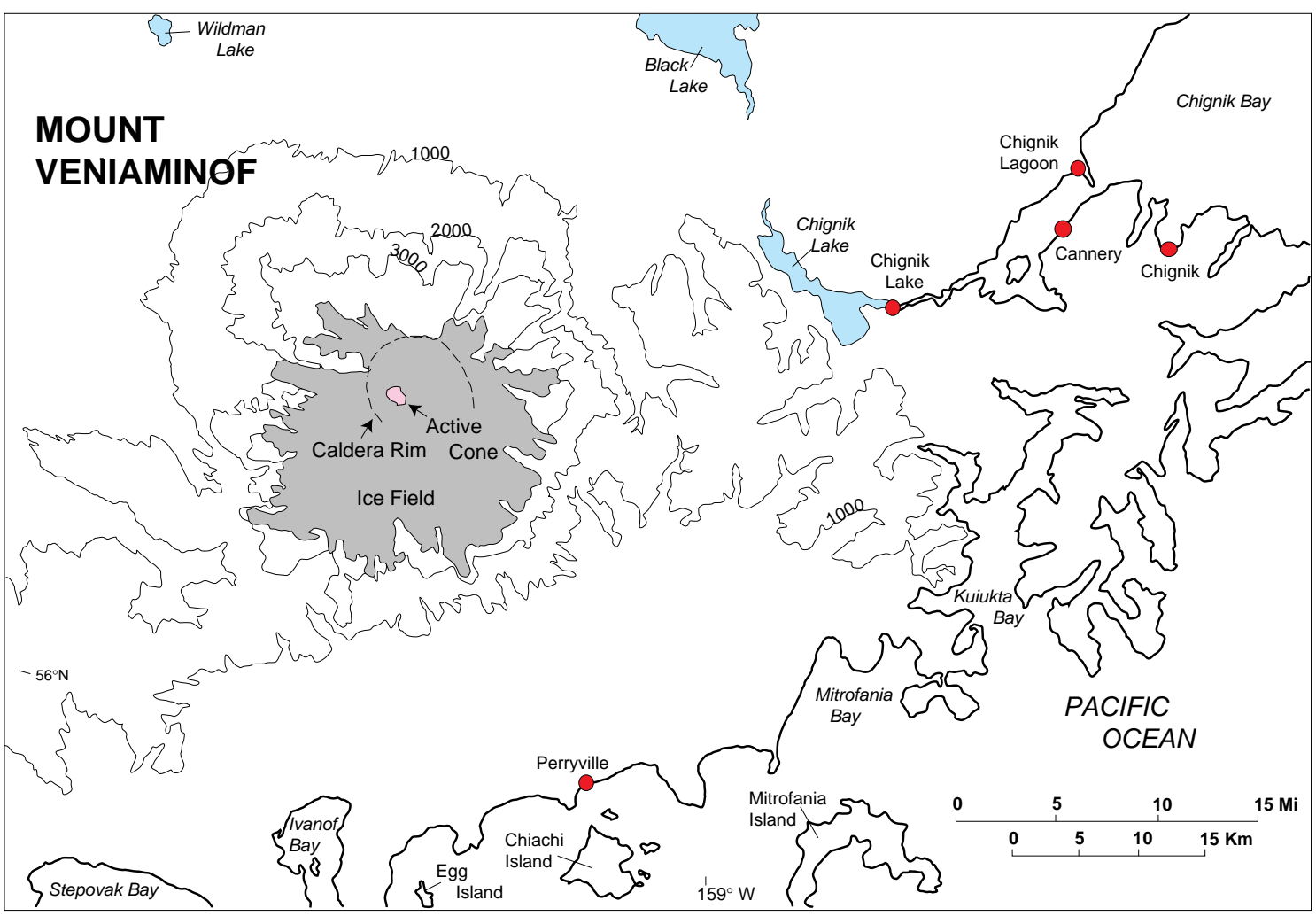

Figure 3. Map of Mount Veniaminof and surrounding area. For clarity, only selected contours (Contour Interval $=1000 \mathrm{ft}$ ) are shown.

Reports of activity at Veniaminof began in early 1993. Pilots reported a steam plume rising from the volcano on February 18, 1993. Confirmed magmatic activity was first sighted on July 30, 1993. Observers in Perryville reported black clouds rising over the summit beginning at 1430 ADT on July 30, 1993. A white steam cloud was present at other times. A small eruption plume was observed on satellite imagery by the NWS on July 30, but none were seen in the following days. On the morning of July 31, Perryville observers saw a gray cloud rising from the volcano and extending to the south. On August 2, commercial airline pilots observed intermittent venting of black ash clouds rising nearly $300 \mathrm{~m}(1,000$ $\mathrm{ft}$ ) above the active intracaldera cone. On August 3, U.S. Fish and Wildlife (USFWS) personnel reported a steaming pit in the snow at base of the west side of the intracaldera cinder cone. Pilot reports on August 3 described black ash and bombs erupting from the 
summit vent of the intracaldera cone at 30-60 second intervals to a height of 2,400 - 3,000 $\mathrm{m}$ (7,900-9,800 ft) above sea level (840 m [2,756 ft] above vent). A minor dusting of very fine ash occurred in Port Heiden after 2000 ADT on August 3, 1993. Residents of Perryville, Chignik, and Chignik Lake also heard a "rumbling noise" accompanied by a slight tremor at about 2200 that night. Flight restrictions around Veniaminof were put into effect August 4, 1993. On the morning of August 6, a resident of Port Heiden observed eruptions of ash and steam at 3-4 minute intervals; these plumes barely rose above the summit of the volcano. There were no reports of ashfall at other nearby villages. On August 12, a pilot reported ash venting 600-900 $\mathrm{m}(1,900-3,000 \mathrm{ft})$ above the crater with the ash cloud carried east-northeast.

Poor weather precluded many observations during the fall. On October 1-2, residents of Port Heiden observed steam and ash emissions over Veniaminof. An Advanced Very High Resolution Radiometer (AVHRR) image from the late morning of October 2 -- the first clear satellite image in almost two months -- showed a faint northeast-directed plume and a thermal anomaly at the summit cinder cone. During the night of October 7 , residents of Perryville observed bursts of incandescent material rising approximately $300 \mathrm{~m}(1,000 \mathrm{ft})$ above the summit. These bursts occurred about once every 10 minutes, were accompanied by loud rumbling sounds, and appeared to be similar in size to the eruptions in July and August. On October 14, residents of Perryville observed continued emission of a gray, steam and ash plume rising about $1 \mathrm{~km}(3,280 \mathrm{ft})$ above the summit. Though the summit was obscured by haze on October 22, observations from Perryville indicated a decrease in the level of activity relative to that earlier in the month.

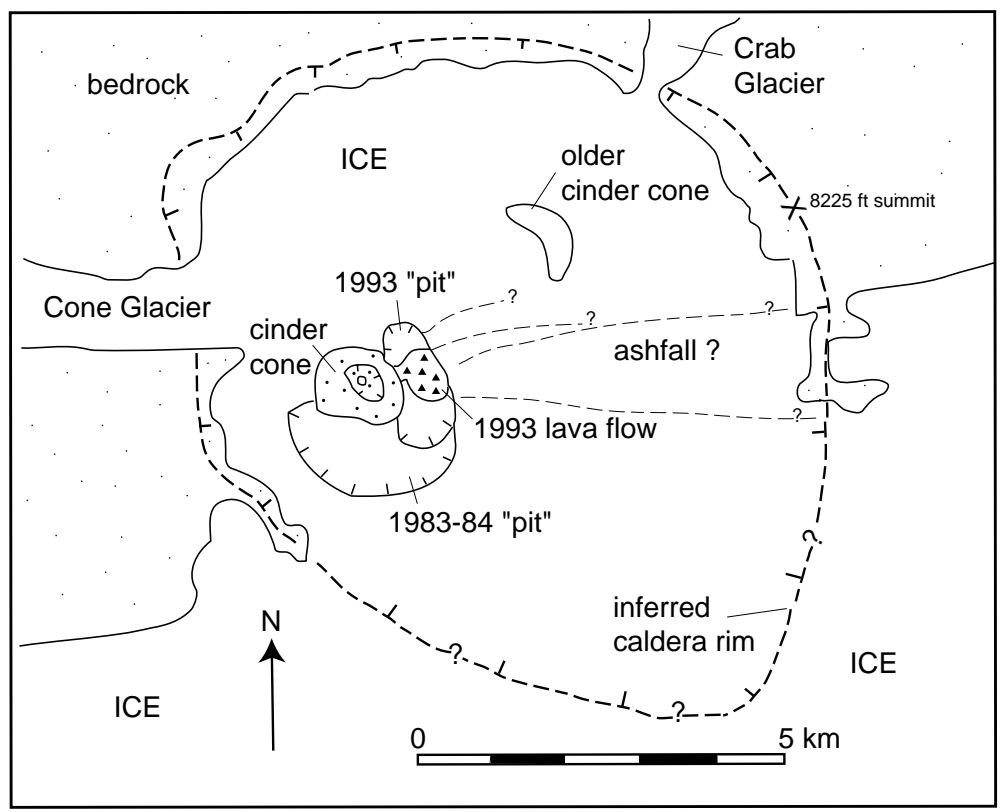

Figure 4. Sketch map of the summit caldera of Mount Veniaminof. Remnant ice pit from the 198384 eruption is from Yount and others (1985). Location of 1993 pit, lava flow, and possible fallout zones derived from USCG video from 11-6-93. 
U.S. Coast Guard (USCG) pilots filmed eruptive activity and took photos of the intracaldera cinder cone on November 6,1993 . By then, a new pit $(2.0$ by $0.75 \mathrm{~km}[1.2$ by 0.5 mi] wide) had formed in the ice adjacent to the cone on the east flank and contained an active lava flow (fig. 4). Steam plumes rose from the outer margin of the lava where it came into contact with the ice walls of the pit. An ash-and-steam plume rose up to $2 \mathrm{~km}$ $(6,560 \mathrm{ft})$ above the cinder cone, and a thin ash layer covered the ice-filled floor of the caldera.

Activity continued intermittently for the remainder of 1993, (for post-1993 activity see Neal and others, 1995). During favorable wind and weather conditions, Port Heiden residents noted dark ash clouds above the volcano and deep rumbling was reported by residents in Port Heiden and Perryville.

The AVO response to the 1993 (and continuing) Veniaminof eruption consisted of frequent (weekly or more) communication with airline pilots, USCG, and USFWS personnel from the Alaska Peninsula National Wildlife Refuge in King Salmon. AVO staff also developed communication links with several residents of Port Heiden, Chignik and Perryville and mailed ash collection instructions and materials in case of significant fallout. (However, no significant fallout has occurred.) Several special information releases were issued and the activity was mentioned in the AVO weekly updates until it appeared the eruption had diminished in intensity or ended. AVO staff in Fairbanks conducted weekly or as-needed evaluations of enhanced AVHRR images of the Mount Veniaminof area as weather conditions allowed.

\section{SHISHALDIN VOLCANO}

$54^{\circ} 45^{\prime} \mathrm{N} 163^{\circ} 58^{\prime} \mathrm{W} 2,857 \mathrm{~m}(9,373 \mathrm{ft})$

Minor phreatic activity? Multiple pilot reports of vigorous steaming and/or "ash" in the fall of 1993. No significant fallout noted.

Shishaldin Volcano is located about $1,100 \mathrm{~km}(680 \mathrm{mi})$ southwest of Anchorage on Unimak Island; the nearest community is Cold Bay, $90 \mathrm{~km}(56 \mathrm{mi})$ to the northeast. In addition to being the highest peak in the Aleutian Islands, Shishaldin is also one of the most consistently active of the Aleutian volcanoes. Strombolian eruptions and ash and steam emission characterize most of the documented historic eruptive activity. Fumarolic activity within the summit crater produces a condensate plume that can be quite vigorous, at times violent enough to contain small amounts of phreatic ash. 
This nearly continuous steam plume from the summit so commonly noted by pilots, was a focus of some attention in September and October, 1993. AVO received a flurry of calls on September 4, 27, and October 4, 1993 relaying pilot reports of vigorous steaming and on one occasion (September 4) "possible ash" to $3 \mathrm{~km}$. This was not confirmed by satellite imagery or ground observations of ashfall. On October 26, an experienced USFWS observer noted ash on the upper $300 \mathrm{~m}$ of the cone as well as a gray coloration to the plume emanating from the summit crater. More pilot reports of steaming were received on October 28. On October 29, USFWS personnel in Cold Bay reported the steam plume was perhaps "darker and more vigorous" than usual; NWS also relayed a pilot report of steam to $20,000 \mathrm{ft}$. Again, no satellite or ground detection of distant ashfall were noted.

The AVO response to this activity consisted of communication with local residents, pilots, the USCG, and USFWS personnel. Pilot observations were mentioned in an AVO weekly update (October 29, 1993). AVO staff in Fairbanks conducted weekly or as-needed evaluations of enhanced AVHRR images of the Shishaldin area.

\section{MAKUSHIN VOLCANO}

$53^{\circ} 53^{\prime} \mathrm{N} 166^{\circ} 56^{\prime} \mathrm{W} 2,036 \mathrm{~m}(6,680 \mathrm{ft})$

Minor phreatic activity? Pilots report strong sulfur smell north of Dutch Harbor on 914-93, 9-23-93, along with "smoke" and steam and ash-darkened snow at Makushin; a USCG cutter sighting of "smoke" on 11-5-93. Possible minor local ashfall; no satellite observations of ash clouds.

Makushin volcano is a broad stratocone located on Unalaska Island about 1,310 km (815 mi) southwest of Anchorage. A summit caldera contains a small cinder cone, eroded remnants of other cones, and several vigorous fumaroles. Except for minor steam emissions, some of which are violent enough to contain small amounts of phreatic ash, there are no records of historical eruptions at Makushin.

On September 14, NWS relayed three pilot reports of sulfur smell northwest of Dutch Harbor and one veteran pilot report of "a trace of ash" at $4000 \mathrm{ft}$. Subsequent investigation turned up the fact that, over the past month, pilots had frequently smelled sulfur and seen "smoke and steam" from Makushin, as well as snow apparently darkened by ash. A similar report was called into AVO on September 23. On November 5, 1993, AVO received a report from NWS relaying a USCG cutter sighting of eruptive activity at 0930 Aleutian Standard Time. AVO and NWS examined available satellite imagery and found no anomaly; calls to residents of Dutch Harbor/Unalaska confirmed no ashfall. A NOTAM was issued by NWS. As phreatic activity is typical at Makushin, AVO distributed no formal information releases at any time. 


\section{SEGUAM (PYRE PEAK)}

$52^{\circ} 19^{\prime} \mathrm{N} 172^{\circ} 31^{\prime} \mathrm{W} 1,054 \mathrm{~m}(3,458 \mathrm{ft})$

Fissure eruption produces lava flow and ash cloud to $3 \mathrm{~km}$ ASL on 12-27-92; effusive and explosive activity resumes intermittently from April through late August 1993.

Seguam Volcano, also called Pyre Peak, is the highest of three young cones on the western half of Seguam Island in the Central Aleutians, $645 \mathrm{~km}$ (400 mi) from the tip of the Alaska Peninsula (fig. 1). The island is remote and uninhabited. The nearest village is Atka, 120 $\mathrm{km}(75 \mathrm{mi})$ to the west. Pyre Peak was last active in 1977 (Smithsonian Institution, 1977). The main hazard associated with the recent eruptive activity at Seguam was airborne ash encounters with low flying aircraft.

On December 27, 1992, USCG pilots reported an ash cloud to 1,200 m (3,940 ft) above Pyre Peak and extending $24 \mathrm{~km}$ (15 mi) north (McGimsey and others, 1995; Smithsonian Institution, 1992). Intermittent bursts of ash rising 100-200 $\mathrm{m}$ above the vent (328 - $656 \mathrm{ft}$ ) and ash accumulation on the south flank were observed on December 30 (McGimsey and others, 1995). The vent was near a satellite cone located $1.5 \mathrm{~km}(1 \mathrm{mi})$ south of Pyre Peak at the north end of a fissure that produced lava fountains in 1977 (Smithsonian Institution, 1977; fig. 5). No subsequent activity was reported until May 28, 1993. Occasional reports of steam plumes and ash bursts reaching as high as 10,000 ft as well as an active lava flow continued into late August, 1993. On August 19, USCG pilots reported a dark ash plume rising from a vent $180 \mathrm{~m}(590 \mathrm{ft})$ below the summit of Pyre Peak. The plume reached an altitude of 2,500 $\mathrm{m}(8,202 \mathrm{ft})$ and drifted east-southeast.

As often occurs in the Aleutians, poor weather precluded continuous observation of eruptive activity at Seguam. AVO monitored the situation by contacting the Coast Guard to verify the location and eruptive activity observed, and by analyzing satellite images and hypothetical plume trajectory plots based on local wind data. A special information release to federal, state, and local authorities and the media was issued and the activity was mentioned in weekly updates for several months. The staff continued daily monitoring of pilot reports, satellite images, and weather data until the activity subsided in late August. 


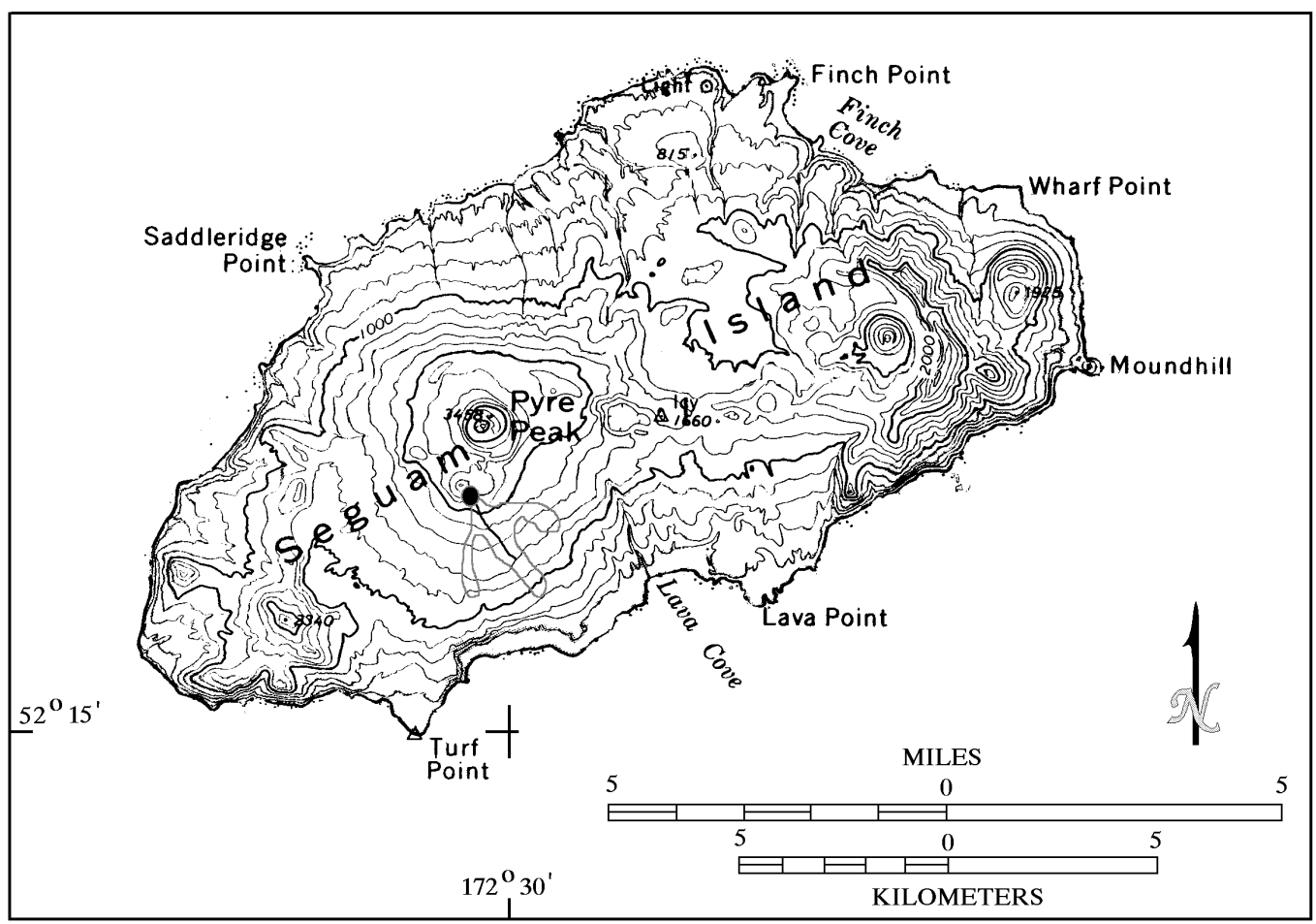

Figure 5. Seguam Island. Vent for 1992-93 activity shown by solid circle just south of Pyre Peak. The thin line enclosing an area extending southeast from the 1992-93 vent shows the approximate area of lava flow coverage and fissure vent active during the 1977 eruption.

\section{KLIUCHEF \\ $52^{\circ} 23^{\prime} \mathrm{N} 174^{\circ} 09^{\prime} \mathrm{W} 1,451 \mathrm{~m}(4,760 \mathrm{ft})$ \\ (FALSE ALARM) \\ Rumbling, strong sulfur smell reported by Atka residents following M 5.1 earth- quake on 12-4-93.}

Kliuchef Volcano (fig. 6) is part of the central Aleutian Atka volcanic center, a cluster of stratovolcanoes of which the most active, Korovin, has erupted perhaps as many as nine times since the early 1800's (Motyka and others, 1993; McGimsey and Miller, 1995). The only historical eruptive activity attributed to Kliuchef occurred in 1812. Atka village is located about $13 \mathrm{~km}(8 \mathrm{mi})$ southwest of Kliuchef. 


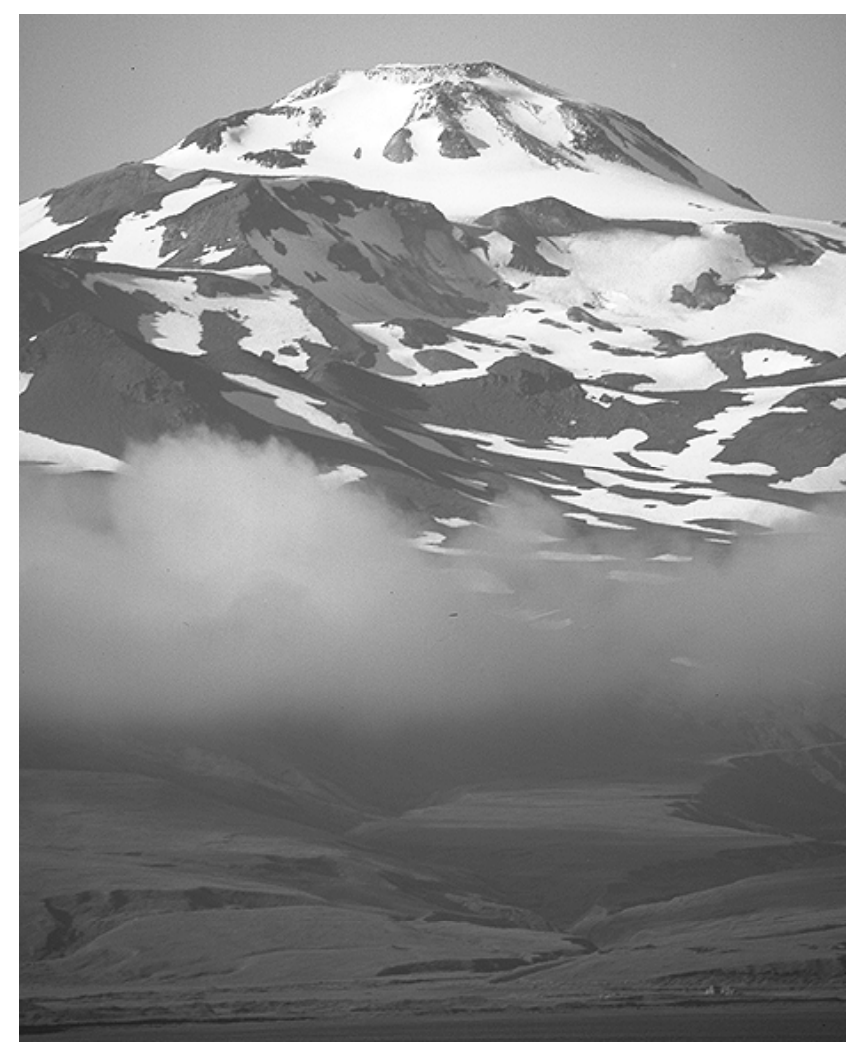

Figure 6. View to the north of Kliuchef Volcano on Atka Island. Photograph by J. Meyers, 9-76.

On December 4, following a M 5.1 earthquake at 17:36 AST (02:36 UTC) beneath Atka Island, residents of Atka village reported "rumbling" from the cluster of volcanoes which form the north part of the island. At the same time, residents observed increased steaming from a long-known fumarolic area on the flank of Kliuchef volcano and noted a distinct sulfur smell. A check of satellite imagery showed no change in the surface state (thermal or ash fallout) of the volcanoes.

\section{KANAGA VOLCANO \\ $51^{\circ} 55^{\prime} \mathrm{N} 177^{\circ} 10^{\prime} \mathrm{W} 1,307 \mathrm{~m}(4,287 \mathrm{ft})$ \\ (PRECURSORY ACTIVITY?) \\ Report of increased steaming by U.S. Navy on 2-17-93*. Additional pilot reports of increased steaming in April and on 12-29-93; eruption begins in January, 1994. \\ *Note: Neal and others (1995) report the first increased steaming observation incor- rectly as April, 1993.}


Kanaga Volcano occupies the northern corner of Kanaga Island in the western Aleutians. It is a symmetric stratovolcano 1,307 $\mathrm{m} \mathrm{(4,287} \mathrm{ft)} \mathrm{high} \mathrm{and} 4.8 \mathrm{~km} \mathrm{(3} \mathrm{mi)} \mathrm{in} \mathrm{diameter} \mathrm{at}$ sea level (fig. 7). The volcano is located about $33 \mathrm{~km}(21 \mathrm{mi})$ west of the U.S. Navy base at Adak Island. Kanaga has been historically active several times in the early part of this century (McGimsey and Miller, 1995).

On February 17, in April, and again on December 29, AVO received pilot reports of increased steaming from the summit crater at Kanaga. Adak residents also reported steaming and an increased sulfur smell in late December. No information release was issued. In retrospect, this unusual fumarolic activity was likely the result of increased heat flux prior to the initiation of the January, 1994 eruption of Kanaga (Neal and others, 1995).

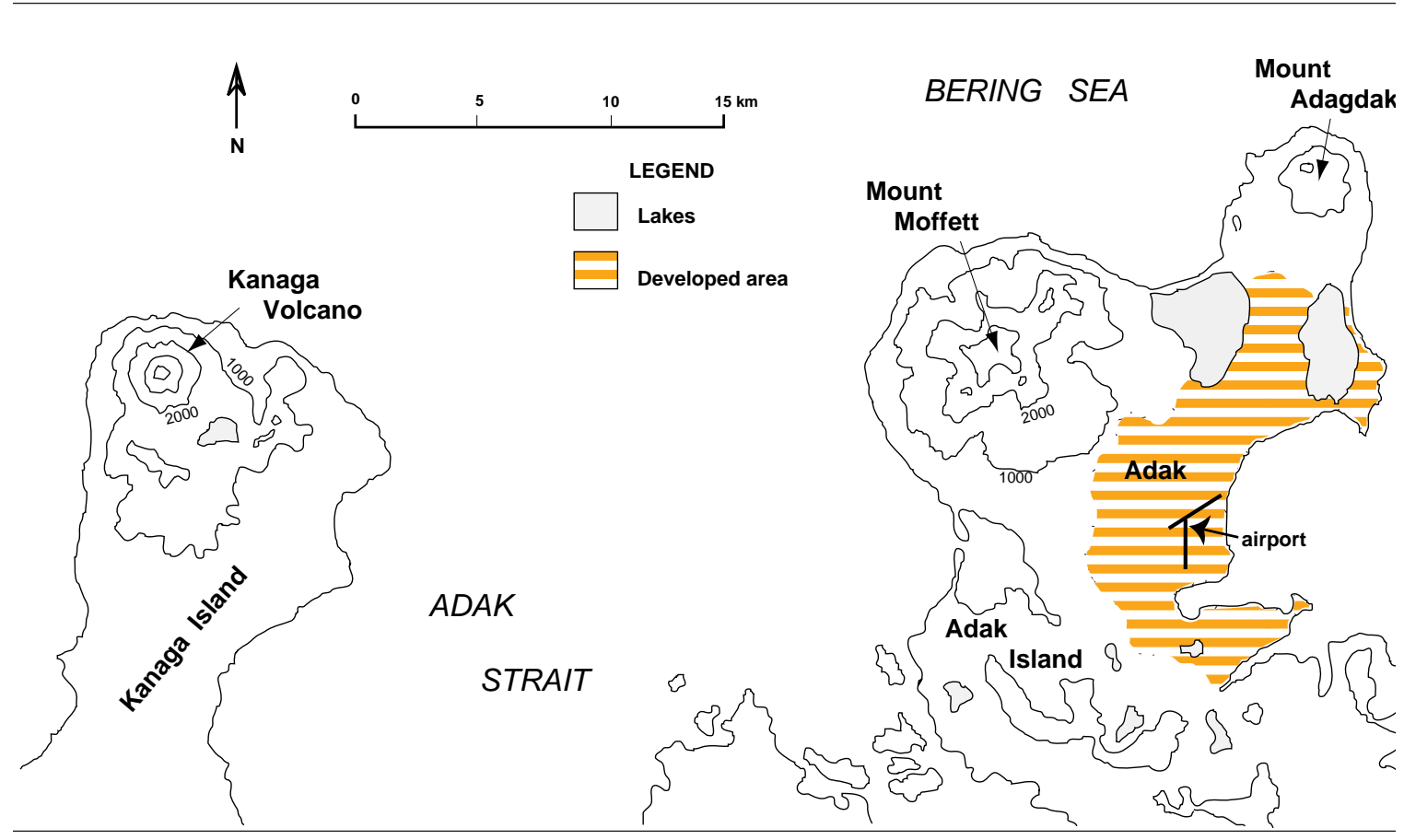

Figure 7. Sketch map of portions of Kanaga and Adak Islands. Contour interval $1000 \mathrm{ft}$. Approximate limits of the community of Adak taken from the 1957 edition of USGS topographic map Adak, Alaska (Alaska Topographic Series, scale 1:250,000). 


\section{ACKNOWLEDGMENTS}

Kathy Lemke assisted with preparation of several map figures in this report. Reviews by Cynthia Gardner and Judy Fierstein improved the manuscript. AVO recognizes the ongoing crucial contributions and cooperation of many federal, state, and private colleagues and associates who provide us with information about volcanic activity in Alaska. In particular, observations from personnel of the U.S. Fish and Wildlife Service, the U.S. Coast Guard, the National Weather Service and the Department of Defense are gratefully acknowledged. 


\section{REFERENCES}

Doukas, M.P., 1995, A compilation of sulfur dioxide and carbon dioxide emission-rate data from Cook Inlet volcanoes (Redoubt, Spurr, Iliamna, and Augustine), Alaska, during the period from 1990-1994: U.S. Geological Survey Open-Report 95-55, 15 p.

Eichelberger, J.C., Keith, T.E.C., Miller, T.P., and Nye, C.J., 1995, The 1992 eruptions of Crater Peak vent, Mount Spurr, Alaska: Chronology and summary, in: Keith, T.E.C., ed., The 1992 eruptions of Crater Peak vent, Mount Spurr, Alaska: U.S. Geological Survey Bulletin 2139, p. 1-18.

McGimsey, R.G., Neal, C.A., and Doukas, M.P., 1995, 1992 volcanic activity in Alaska: summary of events and response of the Alaska Volcano Observatory: U.S. Geological Survey Open-File Report 95-83, 26 p.

McGimsey, R.G., and Miller, T.P., 1995, Quick reference guide to Alaska's historically active volcanoes: U.S. Geological Survey Open-File Report 95-520, 13 p.

Miller, T.P., and Kirianov, V.Y., 1993, Notification procedures for Kamchatka volcanic eruptions: A case history of Sheveluch volcano, April, 1993: U.S. Geological Survey Open File-Report 93-569, 9 p.

Motyka, R. J., Liss, S.A., Nye, C.J., and Moorman, M.A., 1993, Geothermal resources of the Aleutian Arc: State of Alaska, Department of Natural Resources, Division of Geological and Geophysical Surveys Professional Report 114, 17 p.

Neal, C.A., Doukas, M.P., and McGimsey, R.G., 1995, 1994 volcanic activity in Alaska: summary of events and response of the Alaska Volcano Observatory: U.S. Geological Survey Open-File Report 95-271, 18 p.

Nye, C.J., Hammond, W.R., Tytgat, G.C., and Dorava, J.M., 1995, June 29, 1993, Outburst flood from Kidazgeni Glacier, Mount Spurr, Alaska: in: Keith, T.E.C., ed., The 1992 eruptions of Crater Peak vent, Mount Spurr, Alaska: U.S. Geological Survey Bulletin 2139, p. 199-204.

Paskievitch, J.F., Murray, T.L., Hoblitt, R.P., and Neal, C.A., 1995, Lightning associated with the 18 August, 1992 eruption of Mount Spurr, in: Keith, T.E.C., ed., The 1992 eruptions of Crater Peak vent, Mount Spurr, Alaska: U.S. Geological Survey Bulletin 2139, p. 179-182.

Richter, D.H., 1991, Mount Sanford, in: Volcanoes of North America, Wood, C.A., and Kienle, Juergen, eds., Cambridge University Press, p. 87.

Richter, D.H., Preece, S.J., McGimsey, R.G., and Westgate, J.A., 1995a, Mount Churchill, Alaska: Source of the late Holocene White River Ash: Canadian Journal of Earth Science, v. 32, p. 741-748. 
Richter, D.H., Rosenkrans, D.S., and Steigerwald, M.J., 1995b, Guide to the volcanoes of the western Wrangell Mountains, Alaska: U.S. Geological Survey Bulletin 2072, 31 p.

Smithsonian Institution, 1977, Scientific Event Alert Network, v. 2, n.3, p. 8.

Smithsonian Institution, 1992, Scientific Event Alert Network, v. 17, n.12, p. 6.

Yount, M.E., Miller, T.P., Emanuel, R.P., and Wilson, F.H., 1985, Eruption in an ice-filled caldera, Mount Veniaminof, Alaska Peninsula, in Bartsch-Winkler, Susan, and Reed, K.M., eds., The United States Geological Survey in Alaska, Accomplishments during 1983: U.S. Geological Survey Circular 945, p. 58-60.

$* * * * * * * * * * * * * * * * * * * * * * * * * * * * * * * * * * * * * *$

AVO is a cooperative program of the U.S. Geological Survey, University of Alaska Fairbanks Geophysical Institute, and the Alaska Division of Geological and Geophysical Surveys. AVO is funded by the U.S. Geological Survey Volcano Hazards and Geothermal Studies Program and the State of Alaska. 
TABLE 1. Summary of 1993 VOLCANIC ACTIVITY in Alaska (this includes actual eruptions, possible eruptions, and unusual increases in fumarolic activity as determined at the time of the report). Location of volcanoes shown in Figure 1.

\begin{tabular}{|l|l|l|}
\hline Volcano & $\begin{array}{l}\text { Date of } \\
\text { Activity }\end{array}$ & Type of Activity \\
\hline $\begin{array}{l}\text { Mount } \\
\text { Veniaminof }\end{array}$ & $7-30-93^{\mathrm{a}}$ to ? & $\begin{array}{l}\text { strombolian eruption; steam and ash bursts }<1 \mathrm{~km}(3,280 \mathrm{ft}) \text { over } \\
\text { caldera; lava flows within the summit caldera }\end{array}$ \\
\hline $\begin{array}{l}\text { Shishaldin } \\
\text { Volcano }\end{array}$ & fall-93 & $\begin{array}{l}\text { minor phreatic activity; reports of vigorous steaming with possible } \\
\text { ash }\end{array}$ \\
\hline $\begin{array}{l}\text { Makushin Vol- } \\
\text { cano }\end{array}$ & $11-5-93$ & $\begin{array}{l}\text { minor phreatic activity; reports of strong sulfur smell north of Dutch } \\
\text { Harbor; vigorous fumarolic activity; ash-covered snow }\end{array}$ \\
\hline $\begin{array}{l}\text { Seguam (Pyre } \\
\text { Peak) }\end{array}$ & $\begin{array}{l}12-27-92 \text { to } 8- \\
93^{\text {b }}\end{array}$ & $\begin{array}{l}\text { fissure eruption with lava flow and ash plume to } 3 \text { km ASL; activity } \\
\text { intermittent and poorly observed }\end{array}$ \\
\hline $\begin{array}{l}\text { Kanaga Vol- } \\
\text { cano }\end{array}$ & $2-17-93^{\mathrm{c}}$ to ?? & $\begin{array}{l}\text { increased steaming from summit area; probably precursory activity } \\
\text { to } 1994 \text { eruption (see Neal and others, 1995) }\end{array}$ \\
\hline
\end{tabular}

a. earliest known eruptive activity recorded at AVO; possible increased steaming at the intracaldera cinder cone noted in mid-February

b. exact date of eruption cessation unknown

c. first known sighting of increased steaming; first magmatic activity noted in early January, 1994. Note: Neal and others (1995) report the first observation of increased steaming incorrectly as April, 1993.

? eruption continues intermittently into 1995

?? eruption continued intermittently until 10-13-94 as interpreted from satellite imagery (Neal and other, 1995) 
TABLE 2. Summary of FALSE ALARMS in 1993. A false alarm is a report of eruption or possible eruption that requires response but subsequently is determined to be normal or enhanced fumarolic activity, weather-related phenomena, or a non-volcanic event. Location of volcanoes shown in Figure 1.

\begin{tabular}{|l|l|l|}
\hline Volcano & $\begin{array}{l}\text { Date of } \\
\text { Activity }\end{array}$ & Type of Activity \\
\hline $\begin{array}{l}\text { Mount } \\
\text { Churchill }\end{array}$ & $\begin{array}{l}4-5-93 \text { to 4-6- } \\
93\end{array}$ & false alarm; tectonic aftershock sequence located near volcano \\
\hline $\begin{array}{l}\text { Mount San- } \\
\text { ford }\end{array}$ & $\begin{array}{l}4-5-93 \text { to 4-8- } \\
93\end{array}$ & false alarm; visible plume(s) probably from snow/rock avalanche(s) \\
\hline $\begin{array}{l}\text { Mount Spurr/ } \\
\text { Crater Peak }\end{array}$ & $3-14-93$ & $\begin{array}{l}\text { false alarm; 1 hr. of increased seismicity beneath Crater Peak in } \\
\text { response to regional earthquake }\end{array}$ \\
\hline $\begin{array}{l}\text { Mount Spurr/ } \\
\text { Crater Peak }\end{array}$ & $6-29-93$ & false alarm; glacial outburst produces tremor-like seismicity \\
\hline Kliuchef & $12-4-93$ & $\begin{array}{l}\text { false alarm; sulfur smell and fumarolic activity noted after moderate } \\
\text { local earthquake }\end{array}$ \\
\hline
\end{tabular}




\section{GLOSSARY OF SELECTED TERMS}

ash: fine fragments (less than 2 millimeters across) of lava or rock formed in an explosive volcanic eruption

basalt: general term for dark-colored mafic igneous rock, usually extrusive, containing less than 52 weight percent silica

bomb: boulder-size chunk of partly solidified lava explosively ejected from a volcano caldera: a large, roughly circular depression usually caused by volcanic collapse or explosion

cinder cone: small, steep-sided conical hill built mainly of cinder, spatter, and volcanic bombs

fallout: a general term for debris which falls to the earth from an eruption cloud

fault: a fracture or zone of fractures along which there has been displacement of the sides relative to one another

fissure: a roughly linear or sinuous crack or opening on a volcano; a type of vent which commonly produces lava fountains and flows

fumarole: a small opening or vent from which hot gases are emitted

Holocene: geologic epoch extending from the last 10,000 years to present

incandescent: glowing red or orange due to high temperature

intracaldera: refers to something within the caldera

lava: when molten rock reaches the earth's surface, it is called lava

magma: molten rock below the surface of the earth

phreatic activity: an explosive eruption caused by the sudden heating of ground water as it comes in contact with hot volcanic rock or magma

phreatic ash: fine fragments of volcanic rock expelled during phreatic activity; this ash is usually derived from existing rock and not from new magma

regional earthquake: earthquake generated by fracture or slippage along a fault; not caused by volcanic activity

satellite cone: a subsidiary volcanic vent located on the flank of a larger volcano 
seismic swarm: a flurry of closely spaced earthquakes or other ground shaking activity; often precedes an eruption

shield volcano: a broad, gently sloping volcano usually composed of fluid, lava flows of basalt composition (e.g. Kilauea)

stratovolcano: (also called a stratocone or composite cone) a steep-sided volcano, usually conical in shape, built of lava flows and fragmental deposits from explosive eruptions

strombolian: type of volcanic eruption characterized by intermittent bursts of fluid lava, usually basalt, from a vent or crater

subplinian: style of explosive eruptions characterized by vertical eruption columns and widespread dispersal of tephra

tephra: a general term covering all fragmental material expelled from a volcano (ash, bombs, cinders, etc.)

vent: an opening in the earth's surface through which magma erupts or volcanic gasses are emitted

volcano-tectonic earthquakes: earthquakes generated within a volcano from brittle rock failure resulting from strain induced by volcanic processes 